\title{
Tumult (Rejwach)
}

Author: Mikołaj Grynberg

First Published: 2017

Translations: Hebrew (Balagan, 2019); several short stories in English available at: https://jewishcurrents.org/an-excerpt-from-rejwach/ [Accessed: 12.05.2020].

About the Author: Mikołaj Grynberg (1966) graduated in psychology but has been working mainly as a photographer, author, and reporter for three decades. His artistic work focuses on portrait photography, mainly monochrome, e.g. the exhibition Many Women (Dużo kobiet, 2005-2009) showed single shots from women all over the world at every age. Grynberg gains his inspiration mainly from his family history but claims that he "suffers from a sort of obsessive psychosis related with the topic of the Shoah" (Kowalska, 2017, p. 336). His mother survived the war in French orphanages as her parents were deported to Auschwitz and his father survived the Warsaw Ghetto (Grynberg, Titaniec, 2010, p. 117). His 2009-2010 exhibition Auschwitz - What Am I Doing Here? (Auschwitz, co ja tu robię?) gained a great deal of attention (Mazur, 2012). He combines the historical significance of the concentration camp with its contemplative meaning of Jewish fate (Grynberg, 2009) by showing the visitors' reactions walking around the site of mass murder. The monochrome pictures are blurred which makes them more universal. These rather intangible pictures are accompanied by interviews. The text-image link represents the two main aspects of Holocaust remembrance: silence and conversation (Kowalska, 2017, p. 335). Grynberg's technique of giving others a voice in order to understand his own struggle with his family history (Bye, 2020) can also be observed in his interview publications - such as Survivors from the 20th Century (Ocaleni z XX wieku, 2012) and I Accuse Auschwitz: Family Stories (Oskarżam Auschwitz. Opowieści rodzinne, 2014) - in which he transferred his portrait perspective to a textual level. The interviews focus on the memories of survivors and their descendants, often taking up Polish-Jewish relations during and after World War II.

Further Important Publications: Ocaleni $z$ XX wieku (2012, Survivors from the 20th Century; interviews); Oskarżam Auschwitz. Opowieści rodzinne (2014, I Accuse Auschwitz: Family Stories; interviews); Księga wyjścia (2018, The Book of Exodus, biographies).

\section{Content and Interpretation}

Tumult is thus Grynberg's prose debut and continues the topic of Polish-Jewish relations after 1945. It contains 31 short stories resembling snapshots due to their narrative immediacy and brevity that does not leave much space for elaboration. In the story Arkadia ( $\rightarrow$ Night of the Living Jews), the narrator describes Jewish tourists looking despe- 
rately for traces of the Jewish ghetto and brings up their attitude towards Poles. Guiding them to the places of interest, he keeps a safe distance and smiles nicely "so they can feel safe. I am wondering what their parents and grandparents told them about us, the Poles" (Grynberg, 2018, p. 11). Sometimes tourists underline especially: "ju are gud Pol” (p. 12) which confirms the narrator's doubts about the contemporary image of Poles among the Jewish community abroad. Some stories are accounts from the (autobiographic) narrator's past: The German is about the label given to him due to his last name on a holiday camp for teenagers. "During my short life, I was already the Jew who killed Jesus, so I thought that it might be better to be a defeated German" (p. 44). The action of At Hitler's is set during a winter camp at Hitler's former military headquarters, Wolf's Lair. The narrator describes a young boy who was terrified of meeting the ghost of Hitler somewhere in the house and chose to lock himself in the room until departure, while the other boys played tricks on him, and teased him with his fear. The story ends with an unexpected direct address in second person singular mode: "This little boy with glasses that was so petrified by Hitler, was you. It took place in the middle of the seventies" (p. 77). In some stories the autobiographic notion becomes even more obvious, as in The Common Good, where he describes a discussion with the audience after a public lecture. Like in a stream of consciousness, the whole text is made of short statements by the audience expressing disapproval of the author's view on Polish-Jewish history.

"You have to know the limits, for God's sake! Do you want to convince the nation that Jews were Poles?" "To whom do you owe your life? To the Poles after all. We put the lives of our families at risk to save you, you may recall it, Sir. And you only about the Poles being worse than the Germans. If you want to go on living here, you'll have to reconcile with the truth." "Well, who accepted you, when nobody else wanted you? Casimir the Great - Praise him for that." (pp. 87-89).

The latter statement refers to the fact that King Casimir allowed Jewish people to settle in Poland in the 14th century.

\section{Main Topics and Problems}

The Polish Nobel Prize winner Olga Tokarczuk sums up: “These small, searing prose pieces are moving and unsettling at the same time. If the diagnosis they present is right, then we have a big problem in Poland" (Grynberg, 2018). As Tokarczuk shows, the main motif in Grynberg's prose miniatures is the opposition of Us (the Poles) and Them (the Jews); he criticises the obsolete conviction of a binary identity model (as in the Polish-Catholic topos, Polak katolik) that excludes mixtures of faith, ethnicity, and emotional belonging to a group. According to Zając, in Grynberg's prose debut there are no dispensable words; instead of sophisticated poetry the reader gets a rough, awkward reality inspired by the author's interviews or personal experiences but enlarged by the freedom of fiction. (Zając, 2017, pp. 712-714) The author himself challenges the discussion about reality and authenticity since he primarily wants to pass on the feeling of sadness accompanying his life: "I'm sharing my arsenal of sorrow, so 
if readers feel the sadness as I do, then I have succeeded" (Rybicka, 2018, n.p.). He describes his text as follows: "It's edited like a movie: the stories are interwoven, but it's really all about what happens to the reader after they finish reading the last story" (Rybicka, 2018, n.p.).

Another important subject of this prose collection is the topography of memory, which was widely investigated in both Polish and international research on places of Holocaust remembrance (e.g. Suchojad 2010; Ernst, Lamprecht, 2010; Lehrer, Meng, 2015). The disproportionately low number of Jewish (commemorative) spaces in contemporary Polish topography (esp. in the capital but also in smaller towns or the countryside) demonstrates the hierarchisation of the politics of memory, i.e. the lack of significance of the Jewish fate in the Polish notion of history. Although Grynberg is of Jewish origins, he never underlines this directly and identifies with Poland. In his short stories and artistic oeuvre, he takes up an observing position, detaching himself from the discussion (as seen in the last sentence of At Hitler's when he applies the second person mode). This technique aims at making the stories less autobiographical and more inclusive or universal but also bears witness to the ongoing struggle of reconciling Polish and Jewish part of his identity.

\section{Cited Works}

Bye, S. G. (2020). A Conversation with Mikołaj Grynberg. Jewish Currents, 21.04. Available at: https://jewishcurrents.org/a-conversation-with-mikolaj-grynberg/ [Accessed: 08.05.2020]. Ernst, P., Lamprecht, G., eds. (2010). Jewish Spaces. Die Kategorie „Raum“ im Kontext kultureller Identitäten. Innsbruck: Studienverlag. Grynberg, M. (2009). Auschwitz: co ja tu robię? What Am I Doing Here? Was mache ich hier? Oświęcim: Wydawnictwo Państwowe Muzeum Auschwitz-Birkenau. Grynberg, M., Titaniec, M. (2010). Jak tu jestem, to wstydzę się, że żyję. Więź, 625(11-12), pp. 117-125. Grynberg, M. (2018). Rejwach. Warszawa: Nisza. Kowalska, U. (2017). "Prosthetic” Memory, "Aftersights" of Memory, Memory "Easy to Consume"? A Few Words about Visual Remembrance of the Holocaust. Poznańskie Studia Slawistyczne, (12), pp. 331-345. Lehrer, E., Meng, M., eds. (2015). Jewish Space in Contemporary Poland. Bloomington: Indiana University Press. Rybicka, U. (2018). Stranger than Fiction [Interview with Writer Mikołaj Grynberg], Chidusz, 11.04., n.p. Mazur, A. (2012). Decydujacy moment. Nowe zjawiska w fotografii polskiej po 2000 roku. Kraków: Karakter. Suchojad, I. (2010). Topografia żydowskiej pamięci. Obraz krakowskiego Kazimierza we wspótczesnej literaturze polskiej i polsko-żydowskiej. Kraków: Universitas. Zając, M. (2017). O Rejwachu Mikołaja Grynberga. Zagłada Żydów. Studia i Materiały, (13), pp. 708-716.

\section{Further References}

Filipkowski, P. (2015). Między historią mówioną, psychologią ocalenia a traumą drugiego pokolenia. Zagłada Żydów. Studia i Materiaty, (11), pp. 429-444. Janicka, E. (2011). Festung Warschau. Warszawa: Wydawnictwo Krytyki Politycznej. Kuchta, A. (2015). Zawłaszczone narracje. Obrazy postpamięci w zbiorze Oskarżam Auschwitz. 
Opowieści rodzinne Mikołaja Grynberga. Konteksty Kultury, 12(2), pp. 251-264. Majdosz, S. (2017). Pamięć i trauma dziedziczona w Krajobrazie z dzieckiem Romana Grena, Oskarżam Auschwitz Mikołaja Grynberga oraz Pensjonacie Piotra Pazińskiego. Politeja. Pismo Wydzialu Studiow Miedzynarodowych i Politycznych Uniwersytetu Jagiellonskiego, 14(47), pp. 49-62.

EMH 